\title{
Reintegration as a Social Development Strategy for Liberia's Ex-Child Soldiers: Addressing Structural Barriers
}

\author{
Gracie E. Brownell, Marta A. Mercado-Sierra, and Marcella Smith
}

The reintegration of ex-child soldiers remains a primary challenge for post-conflict nations. Very few studies have attempted to provide a structural description of ex-child soldiers' reintegration experiences. This article reports three structural themes uncovered from a phenomenological inquiry into the lives of $34 \mathrm{ex}$-child soldiers in Liberia: poor administration at the program and government levels, constrained opportunities, and social marginalization. The findings support the need to strengthen and hold accountable reintegration structures geared toward ex-child soldiers' well-being as they transition to civilian living.

Keywords: ex-child soldiers, reintegration, post-conflict, structural barriers, social development, Liberia

In post-conflict nations, stakeholders, such as governments, local and international nongovernmental organizations, and communities, are tasked with the challenging task of assisting ex-child soldiers' transition from military to civilian life and contributing to their social development. To achieve this, ex-child soldiers participate in a societal process to reintegrate into society economically, politically, and socially (Lord \& Stein, 2015; Subedi, 2014). However, members of this population faced complex structural barriers during the reintegration process, including but not limited to poverty (Conoir \& Bonard, 2013; Denov, 2010), stigmatization, and lack of family and community acceptance (Betancourt,

Gracie E. Brownell, is a professor of the Texas A\&M University-Commerce, Commerce, TX, USA. Marta A. Mercado-Sierra, is a professor of the Texas A\&M University-Commerce, Commerce, TX, USA. Marcella Smith, is a professor of the Texas A\&M University-Commerce, Commerce, TX, USA. The authors received no financial support for the research, authorship, or publication of this article. Marta A. Mercado-Sierra, Ph.D., Texas A\&M University-Commerce, Commerce, TX, USA. Marta A. Mercado-Sierra can be contacted at Email: Marta.mercado-sierra@tamuc.edu 
Agnew-Blais, Gilman, Williams, \& Ellis, 2010; Denov, 2010; Kaplan \& Nussio, 2018; Kohrt, Tol, Pettigrew, \& Karki, 2010; McMullin, 2013b; Shakya, 2010).

Disarmament, demobilization, and reintegration (DDR) programs provide reintegration services. They must also address the micro-, mezzo-, and macro-level barriers to facilitate successful transition of ex-child soldiers into society. This study came about by building on previous reports on the textural themes that emerged from Liberian ex-child soldiers' experiences during their reintegration process (Brownell, 2019). This study examines the structural dimension of how the Liberian ex-child soldiers experienced the phenomenon, namely, reintegration to their communities and civilian life, and the impact on their well-being.

\section{Literature Review}

People in Liberia experienced two consecutive civil wars for more than a decade (1989-2003), undermining their political, economic, and social development. As in many other countries experiencing civil wars, children and youth involuntarily participated by being abducted, particularly girls who were sexually abused (González Veiga, 2019; Solomon \& Ginifer, 2008). Some joined voluntarily to escape their dire economic reality, in exchange for material goods while others enlisted for reasons such as vengeance, security, and family and peer pressure (Gislesen, 2006; Human Rights Watch, 2005; Peters, 2005). The exact number of child soldiers who participated during the internal wars is unknown. However, several studies estimate that 15,000-21,000 minors were involved in warfare activities with opposition groups such as the Armed Forces of Liberia (Human Rights Watch, 2005). Many of these children are labeled as ex-child soldiers or ex-combatants when they transition to young adulthood expecting to contribute to Liberia's social, economic, cultural, and political post-war development.

On August 18, 2003, Liberia's major stakeholders signed a Comprehensive Peace Agreement in Accra, Ghana, which led to the formation of a National Transitional Government and the implementation of a disarmament, demobilization and reintegration program (United Nations Mission in Liberia, 2020). The following month, the United Nations Mission in Liberia (UNMIL) was established by Security Council resolution 1509 as the implementation arm of the ceasefire and peace agreement processes. This decree gave a pathway to formally establish the National Commission on Disarmament, Demobilization, Rehabilitation, and Reintegration (DDR) in September 2003. Rooted on the ideals of security and peace, the overarching goal of DDR programs is to disarm, demobilize, and enable the reintegration of ex-combatants to their communities and stimulate social and economic development (Ackerman, 2009; International Peace Academy, 2002). In spite of the new standards, DDR programs continued to emphasize the economic portion of development and security priorities.

The Department of Peacekeeping Operations (DPKO) and the United Nations Development Programme (UNDP) under the UN Executive Committee on Peace and Security (ECPS) established the Inter-Agency Working Group on DDR (IAWG) 
on March 2005 with 20 United Nations' (UN) member entities (United Nations, Disarmament, Demobilization and Reintegration (DDR) Resource Centre, 2020). By December 2006, the UN Secretary-General introduced the Integrated DDR Standards (IDDRS) to guide the implementation, and evaluate the effectiveness and the efficiency of DDR programs across countries. However, the traditional focus of DDR in Liberia and other post-conflict states during that period revolved around economic development and not the social dimension, one of the pillars of sustainable development (UN,DDR Resource Centre, 2020).

According to Qerimi (2018), sustainable development came to be the principal global goal throughout the second decade of the 21st century. In 2015, the UN member states adopted The 2030 Agenda for Sustainable Development that defines 17 goals, which transcend economic growth (United Nations, Department of Economic and Social Affairs, Sustainable Development, n.d.). Although all development goals are essential, one of them is particularly relevant to DDR's objectives and the research questions, the Sustainable Development Goal (SDG) 16. This goal promotes peaceful and inclusive societies, provides access to justice for all, and builds effective, accountable, and inclusive institutions at all levels for sustainable development. SDG 16 encourages the global community to "promote peaceful and inclusive societies for sustainable development, provide access to justice for all and build effective, accountable and inclusive institutions at all levels." Qerimi emphasizes on failed or failing states regarding development. His interpretation is that one major flaw moving toward development is weak, ineffective, and unresponsive institutions, including Liberia in the list of countries postwar.

\section{Social Development}

In a world forum, the United Nations' DDR Resource Centre, the World Bank Group's Global Program for Reintegration Support (GPRS), and the Social Science Research Council met in a panel on May 2018. The participants discussed how DDR measures could be applied and adapted to sustainable development (United Nations, DDR Resource Centre, 2020). This panel made evident the United Nations DDR Resouce Centre's commitment to sustainable development and the intersection of their objectives with development goals and strategies in post-conflict countries.

DDR programs' principal goal is to provide support to post-conflict countries building national capacity to stimulate security and stability to contribute to its recovery and long-term development (UN-DDR Resource Centre, 2020). In addition to disarming and removing conflict participants from their militant groups, DRR programs encourage community reintegration facilitating their social and economic participation. DDR programs work closely with local communities to safeguard and support them throughout conflict participants' reintegration process. Thus, DDR programs are to contribute to strengthening communities for long-term development as well as improving ex-combatants' well-being. 
DDR is called to contribute toward the development process of post-conflict countries through assisting communities and facilitating material and nonmaterial sources to advance the well-being of people, particularly ex-soldiers, if we consider the definition of development of the Declaration on the Right to Development:

...comprehensive economic, social, cultural and political process, which aims at the constant improvement of the well-being of the entire population and of all individuals on the basis of their active, free and meaningful participation in development and in the fair distribution of benefits resulting there from,... (United Nations, 1986, Annex section, para. 2)

Pillai (2017) described development as "a process of economic, social, cultural and political character" to continuously and purposely improve the well-being of each individual and the entire population. To move toward development, we need to focus on the social dimension of development. To improve people's well-being, governments need to create and manipulate the structures and conditions (Pillai, 2017), public policies, services, and programs. In other words, governments need to plan to make resources available and accessible to their communities.

Governments (local, state, national, and international) need to define the conditions and the impact desired and the strategies to influence or develop the necessary conditions to improve all people's quality of life . Figure 1 represents the interconnection between the macro dimension of social development and the micro dimension of well-being of all people.

United Nations Development Program (UNDP, n.d.) measures development by its impact on people and defines the phenomenon as the process to expand people's choices. These conditions determine the constraints or opportunities to

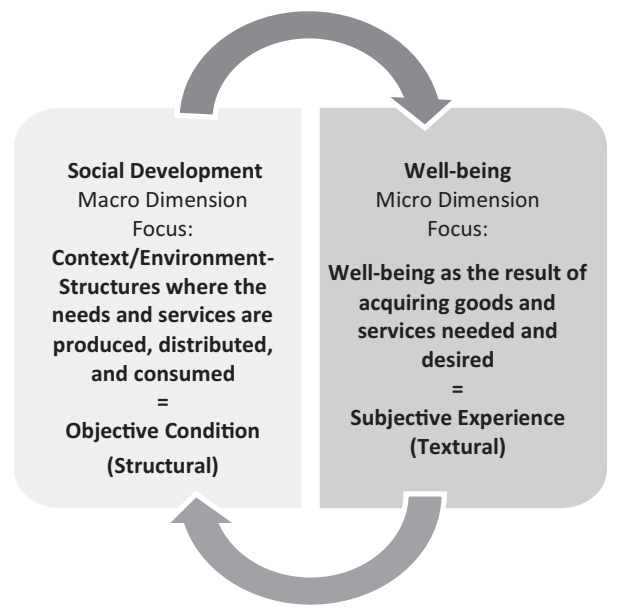

Figure 1 Interconnection between social development and wellbeing 
access material and nonmaterial goods (Pillai, 2017). Podder (2010) concluded recruitment and reintegration experiences in Liberia were ineffective due to macro-level issues of economic underdevelopment, widespread political instability, and continued infrastructural and institutional lapses. In conclusion of the peace agreement, the UNMIL completed the transfer of security responsibilities to Liberian authorities successfully on March 30, 2018 (United Nations, Mission in Liberia, 2020).

\section{Reintegration Experiences}

In Liberia, reintegration efforts spearheaded by the DDR program were criticized as the weakest link (Podder, 2012). Reintegration proved to be a challenging process for DDR programs (Giustozzi, 2012; McMullin, 2013a; Bowd \& Ozerden, 2013). Research shows little evidence of DDR programs meeting their intended outcomes (Agbedahin, 2018; Dudwick \& Srinivasan, 2013; Munive \& Stepputat, 2015; Schulhofer-Wohl \& Sambanis, 2010). Efforts to assess the immediate outcomes of DDR programs have shown mixed results.

Community reintegration takes more time to achieve in comparison to economic reintegration (Zena, 2013; United Nations Children's Fund (UNICEF), 2009). While some studies showed actual social and economic benefits in ex-combatants who participated in reintegration programs in Liberia, other studies failed to assess any notable benefit in Sierra Leone and found significant barriers in social and economic reintegration, especially for females (Kilroy, 2014; Solomon \& Ginifer, 2008). Although many female ex-soldiers participated in frontline battle zones in the Liberian wars, initial programs were limited, and the existing ones did not respond to their security and sanitary needs (Solomon \& Ginifer, 2008). Solomon and Ginifer (2008) stated that women ex-combatants were not only rejected by their family members due to the lack of economic means but also stigmatized during the reintegration process. Their study revealed that their families and communities had rejected $90 \%$ of the "bush wives." Many of the women ex-combatants who return home to families and communities experience high levels of abuse (Ferreira \& Stuart Muttiti, 2016). Solomon and Ginifer (2008) concluded that the community response to fear, denial, discrimination, and stigma have accompanied females associated with armed conflicts. Furthermore, Podder (2012) found that social bonds were weakened by the loss or rejection of family members due to war crimes committed. This created tension and hostility and made reintegration into their community of origin more complicated.

Besides community acceptance, the DDR program complained about administrative efficiency and bureaucratic design (Solomon \& Ginifer, 2008). Participants faced obstacles such as unemployment, lack of tools, or program completion certification (Brownell, 2019). Although the reintegration program sought to provide ex-combatants, including ex-child soldiers, with educational opportunities, computer training, and vocational skills training 
(Kaplan \& Nussio, 2018; McMullin, 2013a; United Nations, DDR Resource Centre, 2020), it received heavy criticism. Like DDR programs in Somalia, Liberia's DDR program has been condemned as ineffective because of its vague mandate, lack of funding (Ferreira \& Stuart Muttiti, 2016;Zena, 2013; UNICEF, 2009), and lack of research (Hanson, 2007). Similar findings point to inadequate and untimely reintegration opportunities, discontinuity in funding (Awodola, 2012), the lack of reliable data, and the use of money to incentivize ex-child soldiers' participation (Palmer, 2006).

Both ex-combatants and local communities understand that sustainable demobilization and reintegration initiatives lacked planning and programming based on participants' needs and concrete opportunities in the local communities (González Veiga, 2019; Solomon \& Ginifer, 2008). Participants also argued that DDR programs lacked a clear monitoring system, corrective measures, and follow-up mechanism at the community or individual levels. Furthermore, assistance was not provided to ex-combatants who did not reintegrate and develop to their fullest potential (Solomon \& Ginifer, 2008).

Participants who experience discontent with reintegration expressed they were unable to change their circumstances in the absence of reintegration aid or government intervention - they felt powerless against the authorities and blamed them for not facilitating their reintegration into their communities. The feeling of incapacity and helplessness puts them at risk of becoming marginalized and excluded from cultural, political, economic, and social development activities (Brownell, 2019).

Besides descriptive literature on the national DDR program launched by the UN and other international organizations (United Nations, DDR Resource Centre,2020), there is a small body of literature on the significant role nongovernmental organizations (NGOs) played in ex-combatants' reintegration, especially in the areas of formal education and skills training (Tonpo, 2006) as well as their participation in politics (Söderström, 2009). The United Nations DDR Resource Centre (2020) describes a successful reintegration program as one whose administrators plan, manage, and implement a coherent and effective DDR strategy.

Although reintegration programs were implemented in post-conflict nations since the late 1980s (UN, DDR Resource Centre, 2020), a lack of empirical proof of its effectiveness remains. This condition is due to the recent nature of its development, inconsistencies in intervention methods, and the limited research conducted to evaluate them (Fegley, 2008). The absence of professional and analytic literature on ex-child soldiers' reintegration can also be attributed to Liberia's 14 years (1989-2003) of civil war (Ansorge \& Antwi-Ansorge, 2011), a period in which minimal studies were conducted and published.

Pugel (2007) learned that DDR participants in Liberia reintegrated at higher rates when completing a course than their counterparts attempting to reintegrate independently. The primary reintegration services offered to ex-child soldiers were educational support, skills acquisition, and family reunification (Awodola, 2012). 
Similarly, Levey et al. (2013) found that family reunification and community reintegration would benefit former child soldiers. In contrast, Conoir and Bonard (2013) considered education or vocational skills training as the first step in economic reintegration. Another research suggested that successful reintegration chances are higher if ex-combatants undertake formal vocational training (Finn, Baxter, \& Onur, 2014).

In a post-conflict setting like Liberia, effective peace education plays an integral role in reintegrating former child soldiers. Peace education stimulates empathy, cooperation, reconciliation, and community processes for handling conflict in a nonviolent manner, all of which are essential factors in preventing former child soldiers from re-engaging in violence and terrorism (Wessells, 2005). Sam-Peal (2008) proposed the simple process of listening to child soldiers' life stories and dreams as a constructive and meaningful interaction that affirms each former child soldier's value as they reintegrate into their communities.

At least two pilot studies evaluated reintegration interventions in Liberia (Gregory \& Embrey, 2009; Lekskes, van Hooren, \& de Beus, 2007). The first pilot study evaluated a 2-week group training and one-on-one companion recovery intervention designed to reduce the symptoms of Post-Traumatic Stress Disorder (PTSD) among former Liberian child soldiers. These studies found that the model significantly $(p \leq 0.001)$ reduced participants' PTSD symptoms by $33 \%$ (Gregory \& Embrey, 2009). In the second pilot study, researchers evaluated the effectiveness of two psychosocial interventions (counseling versus support group and skills training) for female victims of war-related and sexual violence in Liberia. They found that while both interventions were successful, counseling was more effective in reducing trauma symptoms as compared to the support and skills training (Lekskes et al., 2007). Jennings (2007) argued that reintegration programs could be strengthened by allocating resources toward developing and implementing open-access job programs, particularly for vulnerable groups such as ex-child soldiers.

While the literature points to the reintegration program deficits, no study has examined how ex-child soldiers experience reintegration. Thus, this phenomenological study sought to answer the following research question: How did ex-child soldiers experience reintegration in Liberia? What structural barriers do Liberian ex-child soldiers experience during reintegration?

\section{Method}

Although a few studies evaluated the reintegration programs (Awodola, 2012; Druba, 2002; Hanson, 2007), no study has used phenomenology to identify ex-child soldiers' experiences. Rather than using scientific theories to describe reintegration, in this study, the phenomenological method lets researchers rely on the subjective truths and understandings of individuals who experience the phenomena first-hand. A phenomenological inquiry method allowed the inclusion of the "textural description" of participants' experience as well as a "structural 
description" of the context and settings of their reintegration experience and was interpreted by the researcher (Moustakas, 1994). While dissatisfaction with reintegration, powerlessness, and perceptions of no or partial reintegration were three textural themes identified in a previous report (Brownell, 2019), this study focuses on the structural themes of reintegration as experienced by 34 ex-child soldiers living in Liberia.

The secondary data used in this study derived from the interviews of 34 adult child soldiers who lived in or near Monrovia, Liberia's capital. Following Institutional Review Board (IRB) approval by the Baylor University, the Monrovia Vocational Training Center, an agency contracted to implement the DDR program in Liberia, recruited the participants for the study. Since it was a convenience sampling, interviews were conducted both in-person and via telephone. The researcher developed an interview guide of open-ended questions drawn from previous research (Paes, 2005; Pugel, 2007), experts' feedback, and a few members of the ex-child soldier population. Prior to the interview, participants provided demographic information including age, gender, combatant status, participation in previous phases of the DDR program, DRR program completion, education level, vocational skills training, employment, income, marital status, and number of children.

The revised version of the Van-Kaam phenomenology method of analysis presented by Moustakas (1994) guided the data analysis. Epoche, the first step of Moustakas' phenomenological analysis process, helps qualitative researchers to set aside preconceived views derived from self and others to concentrate on the participants' perspectives (Moustakas, 1994). In the following section, the primary researcher described her experience with the phenomenon of child soldiering to capture her personal views, beliefs, and biases intentionally.

I have always been interested in studying the Liberian ex-child soldier population. Growing up in Liberia during the civil war, I was exposed to child soldiering for a significant period of my childhood and adolescence. What I knew about child soldiering then was limited to rumors of children being abducted from other families until my family became victimized. At the beginning of the civil war, my mother's teenage sister was forcibly taken from our home to serve as a domestic help and was later forced into becoming a rebel's wife. I also remember seeing young soldiers weighed down by their guns at the checkpoints, say hello, and reintroduce themselves to my father as his former students.

Throughout the war, I sympathized with young soldiers and was concerned about their future. After the war ended, many became homeless and were considered "street children" who were discriminated against and harassed, both verbally and physically. I formed the opinion that those ex-child soldiers were both victims and perpetrators of the war. After moving to the United States to pursue higher education, I was introduced to various theories on children's growth, development, and behavior. This exposure led me to wonder how a problem like child soldiering impacted the future of children who fought in the Liberian civil war. I realized that there was a lack of published literature on child soldiering and 
reintegration in Liberia. At that point, I vouched to understand and help this population through research.

I then began to build and maintain relationships with reintegration programs, including the National DDR program Director. The following assumptions are based on my personal experiences, and the literature review I conducted in preparation of this study: ex-child soldiers are victims who the society failed to protect; they were abandoned by their military groups, the government, and often blamed by communities while being victims of their actions during armed conflicts; the economic and social disparity between this group and the rest of the society will continue to increase in the absence of appropriate interventions; and ex-child soldiers are more likely to engage in future armed conflicts if they are not empowered to meet their basic needs.

To do this and set aside all preconceived notions, I employed reflexivity, which, according to Padgett (2008), is the ability to examine oneself. Throughout the study, I reviewed my biases and also documented personal and professional reactions to findings in the literature review and data analysis process as indicated by Padgett (2008). By practicing reflexivity, I sought to become self-aware politically, culturally and own my perspectives in reagards to child soldiers (Patton, 2002).

After setting aside my beliefs and biases through bracketing, I used Moustakas' (1994) strategy of horizonalization. I read the transcripts of each interview using the NVivo software. I viewed each statement as equal while keeping an open mind about how participants' responses related to this study. The third step involved identifying and highlighting unique statements or expressions from each participant's responses. Moustakas referred to these unique statements or expressions as invariant horizons or meaning units, known as nodes in Nvivo. Following the identification of these invariant horizons, the primary researcher determined whether those unique statements or expressions were important and provided insight into the participants' reintegration experiences. Concluding this step, I provided short description labels for the statements or expressions that I determined to be unique, important, and insightful. Then, I examined the statements and expressions that I highlighted to establish relationships, particularly similarities. Those statements and expressions that were alike were clustered into themes, and I provided a short description label for each theme. I used the identified meanings and themes to build an overall description of how and what each participant's experience was during reintegration. The construction of participants' experiences using identified units and themes is known as textural-structural description (Moustakas, 1994). As Moustakas (1994) proposed, I constructed individual textural-structural descriptions for each participant, which resulted in a composite texturalstructural description. The synthesis of individual textural-structural narratives revealed meanings of the shared lived experiences of ex-child soldiers' reintegration in Liberia.

The term "structure," as defined by Keen, refers to "that order embedded in everyday experience which can be grasped only through reflection" (as cited in 
Moustakas, 1994, pp. 78-79). The underlying or structural themes in this study surfaced by reflecting on the researchers' experience, which included reading the transcripts, notes from the data collection, and analyzing the data.

Describing the connection between texture and structure, Moustakas (1994) noted, "the relationship of texture and structure is not that of object and subject or concrete and abstract but of the appearance and the hidden coming together to create a fullness in understanding the essences of a phenomenon or experience" (p. 79). Unlike the textural themes of dissatisfaction, powerlessness, and perceptions of no or partial reintegration, which revealed what Liberia ex-child soldiers experienced during reintegration (Brownell, 2019), the underlying or structural themes emerged in this study describe how participants experienced reintegration. Based on data analysis and a deep reflection of the researchers' experience, the following three structural themes were identified: poor administration at program and government levels, constrained opportunities, and social marginalization (see Figure 2).

\section{Limitations}

Firstly, this study used a qualitative design drawing upon secondary data; hence, this study's findings are not generalizable. Secondly, recall bias may have occurred since participants' responses to questions about the reintegration experiences depended on their memory of their experiences. Thirdly, since all the interviews were completed following the DDR program, participants' descriptions of their reintegration experiences may reflect the perceptions and views they held at that

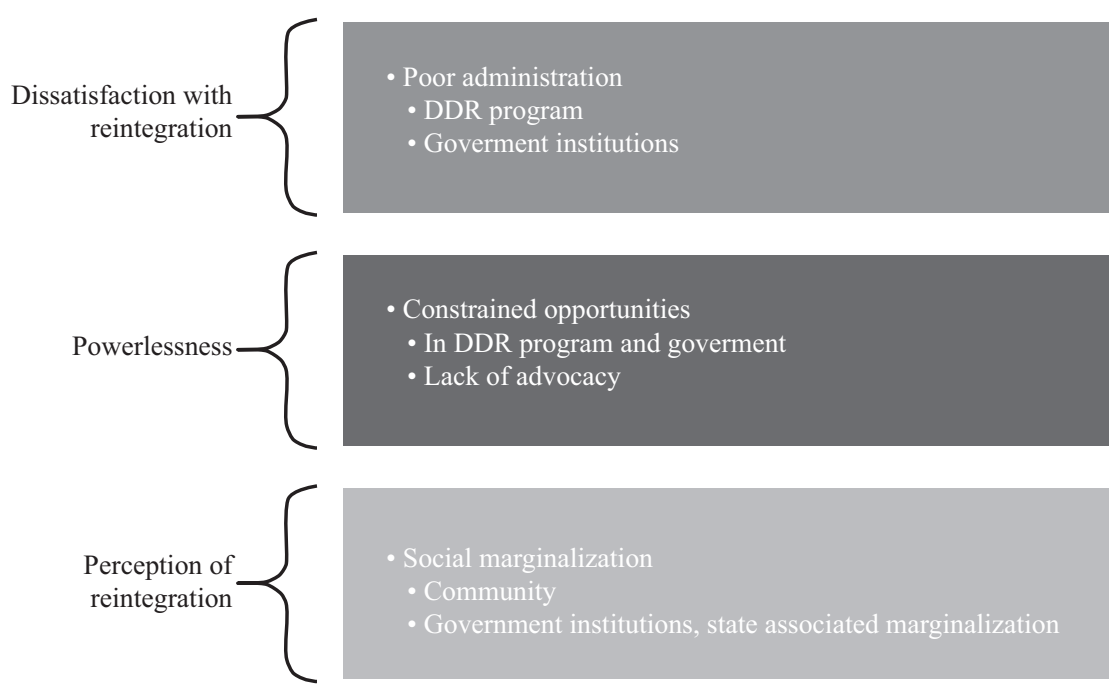

Figure 2 Textural \& structural themes 
particular point of time. Furthermore, since the study is based on secondary data, the researcher cannot utilize member checking, which involves asking for input from participants for validation purposes (Guba \& Lincoln, 1989).

\section{Findings and Discussion}

The sample was composed of 34 participants ( 14 females and 20 males) aged between 19 and 42 years. On average, the participants were 33.3 years old at the time of the interview and 13.8 years of age at the beginning of the Liberian civil war. Seventy-nine percent completed the disarmament and demobilization phases of the DDR program. A little over half of the 34 participants (59\%) had an elementary-level education, while $29 \%$ and $12 \%$ reported a junior high and high school level education, respectively. The majority of the participants were married $(82 \%)$ and had an average of two children. When asked about the educational path they pursued during the DDR program's reintegration phase, $26 \%$ were enrolled in a formal academic program. In comparison, the majority pursued tailoring $(32 \%)$, agriculture (32\%), and plumbing (12.7\%). Only one participant disclosed being employedand was the only one who pursued vocational training in electricity.

\section{Poor Administration at Program and Government Levels}

Among the participants, the most prominent and prevalent structural theme that emerged was poor administration at the program and government levels. This structural theme emerged from two textural themes: dissatisfaction with reintegration and perceptions of reintegration (Brownell, 2019). The majority of the participants in the study expressed disapproval with their reintegration and subsequently reported no or partial reintegration primarily due to inadequacies highlighted when describing their interaction with both the DDR program and the Government of Liberia. All but one participant in this study experienced poor administration at the DDR program and at the government level. Participants experienced irregularities and disruption of reintegration assistance while enrolled in vocational skills training in the DDR program. Due to poor implementation and poor oversight of the DDR program, ex-combatants' vocational skills training and reintegration assistance were plagued by irregularities and abrupt disruptions in services. In their accounts of the reintegration experience, the participants pointed out discrepancies between what they were told would happen while enrolled in the DDR program and what they experienced. A participant stated, "The program did not give us all the benefits and ended all of a sudden" (Male/P3/Unemployed). While another said:

All the things they promised us like training, counseling, money, and even resettlement were all lies. Those who were heading the programs didn't 
fulfill their promises to us. I am feeling bad. Since we were promised what we were told would be given to change our condition, nothing has been done. (Male/P12/Unemployed)

\section{Likewise another noted:}

The nine months we were told that our courses would end was a waste. Teachers irregular, stipend not coming, we left even before the nine months were over. As a result, we never comprehended anything. Our names were already in some of the targeted schools. What surprised us was that, though we had the ID Cards, we were already in school. So when we go there, to the school, we were already in school. What a shock.

Somebody was benefiting from us. What hurt us most was that we were only cards holders. After numerous complaints, we were not given any satisfactory answers. No one was concerned about us. We had nothing to do that will occupy our time. (Female/P7/domestic worker)

The irregularities in the DDR's administration and implementation of services that participants in this study experienced are similar to those experienced by other ex-child soldiers in Liberia and Sierra Leone (González Veiga, 2019). During the reintegration phase, Liberia was marred by structural challenges such as lack of qualified teachers and the lack of support for schools (Jaye, 2009), which helped decrease ex-child soldiers' expectations of the program (González Veiga, 2019).

Adults who served as soldiers during their childhood have different experiences and needs as compared to their adult counterparts who were recruited and had served in armed conflicts as adults. Therefore, reintegration program strategies and delivery must reflect these differences. González Veiga (2019) noted that the lack of flexibility in the structures of reintegration programs increases discrimination and marginalization for children associated with armed forces and groups. "I was thinking they was [sic] putting us to a good place for 2 or 3 years, for them to make us come to ourselves for good to be good in society, but then again they said six months" (Male/P2/Unemployed). Consequently, participants described feeling abandoned, victimized, frustrated, dissatisfied, unhappy, and poor during their reintegration process. A child soldier participant recalled his completion of the vocational skills training program, "I graduated from the school. One of the $\mathrm{R}$ (reintegration) left. The people never got back to us. They only told us that they were finished with us" (Male/P13/Petty Trader).

Another manifestation of poor administration that impacted participants' reintegration occurred at the government level. An important aspect of poor administration at the government level is the concept of state-associated marginalization. In this study, ex-child soldiers experienced state-associated marginalization when the government failed to advocate for their economic and social participation or provide reintegration assistance beyond the DDR program. One 
participant described the sudden interruption she experienced while participating in a government-funded reintegration program:

I was going to agriculture school. The first 250 people graduated and we were the last 150 people but we never graduated. They call the man McIntosh and the school ADA. The school never gave us our benefit. The DDR program was not completed. The government closed the program down because it was not complete. (Female/P9/Unemployed)

This state-associated marginalization contributes to feelings of abandonment among participants. One male participant stated, "We need to get back to school, return to our villages, and so forth, but they in power are not prepared to listen to us. We have been totally abandoned" (Male/P12/Unemployed). Several participants highlighted the role of the government in their reintegration. One participant said, "I hope the government can come to our rescue or else our children and we will remain in poverty" (Female/P14/Unemployed). As a result of poor administration at program and government levels, participants perceived their reintegration as incomplete. For example, one participant remarked, "If the people don't come back and have me reintegrated, it means that I don't have hope. I pray to God that some people will come and help to carry on the process, for the process is not completed" (Female/ P5/Unemployed).

These findings are similar to previous literature that argues that when it comes to reintegrating ex-child soldiers, the international community's primary challenge is overcoming the legacy of bad governance in Liberia (Paes, 2005). Other weaknesses of the DDR process, identified in previous research that was also evident in this study" "s findings, include the fact that reintegration opportunities were not provided in an adequate and timely manner, and some discontinuity in funding (Paes, 2005). Other documented problems with the DDR program in Liberia include cheating, exclusion, lack of access, escalated enrollment, and inflated caseloads (Podder, 2010). These administrative weaknesses directly impact the quality and length of reintegration assistance that ex-child soldiers experienced in this study.

\section{Constrained Opportunities}

The poor administration at the program and government levels is directly connected to the constraint of opportunities the participants experienced during their reintegration process. As a result of these constrained opportunities that resulted from not receiving reintegration assistance as promised, ex-child soldiers described a state of stagnation wherein they admitted, expressing "still waiting for my benefit" (Male/P20/unemployed) and "Right now, I sit home and do nothing. I hope they will start to treat us better and give us an opportunity to learn and get jobs" (Male/P7/Unemployed). DDR programs contribute to poor economic conditions among ex-child soldiers when they fail to develop and implement effective transitional livelihood opportunities (Solomon \& Ginifer, 2008). 
One participant described being "hopeful" (Male/P20/Unemployed) about his reintegration outcomes before participating in vocational training. The majority of ex-child soldier participants indicated that their reintegration experience consisted of a period of "waiting" for reintegration assistance. They were previously promised, including the reopening of disrupted reintegration programs, vocational skills training, and assistance in securing employment or starting a petty trade. Expressing anticipation for government assistance during this waiting period, one participant disclosed:

I am waiting. The day the people from the government bring anything satisfying, I will appreciate it. Anything like zinc and any building material or they offer me the right job, give me business I will appreciate it. I will need cash. Any amount that they will be willing to give me is fine. (Female/P2/ Unemployed)

The constrained opportunities participants experienced during reintegration were tied to unsuccessful completion of vocational skills training, lack of certification, lack of tools, subsequent unemployment, and lack of government support. Similar findings suggest a link between poor administration of the DDR program, marred by unprofessional skills training courses, a lack of quality control, and complex management structure involving multiple agencies, and constrained opportunities partly due to the program's failure to link participants to market opportunities (Solomon \& Ginifer, 2008). Only one negative case reported employment obtained without help from the reintegration program. An aspect of constrained opportunities noted by participants was an "indefinite waiting period" during which they anticipated the fulfillment of reintegration assistance previously promised. Research indicates that since April 2004, several thousand ex-combatants have been waiting for reintegration benefits (Paes, 2005).

During this waiting period, ex-child soldiers rely on God, family members, humanitarian agencies, local and international communities, and it is this reliance that Corbin (2008) suggested, "may lead to a breakdown of appropriate social responsibilities around self-sufficiency" (p. 322). This is consistent with the findings, with the exception of the participant who was employed. All the other participants admitted relying on family members or engaged in petty trade as a means of livelihood. In Sierra Leone, female and male ex-soldiers did not experience adequate protection and benefits, which left them impoverished, vulnerable to exploitation and violence, with their primary means of income being sex trade, theft, and petty trading (Solomon \& Gifiner, 2008). On the other hand, many of the participants felt marginalized by their community.

\section{Social Marginalization}

Another central structural theme that emerged was the social marginalization this population faced when returning to their communities. For the most part, 
participants in this study described feeling ostracized, disconnected, and unsupported by community members who were unfriendly toward them, including members of their families. For example, one of the participants disclosed, "We have not been reintegrated well. I'm not really fine. We were not treated well. Daily passersby insult us calling us names like rebels. Even though I'm in school, I'm paying my fees" (Male/P17/Student).

An essential aspect of social marginalization is the lack of advocacy for ex-child soldiers to be recognized and accepted as community members, capable of contributing to society through the labor market following successful completion of the DDR process"' 's previous phases. The importance of advocacy in social marginalization is captured in this participant's comment:

We went through the war unhurt. Then the time came for disarmament. We were taken to VOA site and were promised a lot of things. We were sent to do all kinds of trainings. When we return to Monrovia, some of us main reason was to come and live with our brothers and sisters. But to our utmost surprise, attacks and insults started to rain on us. Everyone started to sideline us. The government didn't help in any way. Realizing what kind of experiences we were facing, we regretted that we had to disarm. By disarming our respect were taken away. If we had our arm no one will dare do such thing to us. This brought back flashes of the war. (Female/P14/Unemployed)

One study found that when compared to male ex-soldiers, female ex-soldiers and "bush wives' who served as sex slaves to the commanders experienced discrimination and rejection from their families and communities (Solomon \& Ginifer, 2008). Community and participants who experienced less or no social marginalization appeared to have more connections with their community members, resulting in employment and community acceptance. For instance, one participant indicated some type of positive relationship with members in his community by stating, "I did plumbing at the LOIC, we were told that when we completed the training, they were going to find job for us. Since then, nothing. If I did not sell used clothing for people, I will not eat." (Male/P8/Petty Trader) Only one participant disclosed that he felt accepted by his community, and because of his employment, he considered himself a positive contributor to his family and community.

The structural theme of marginalization, as experienced by participants in this study, is similar to ex-child soldiers' experiences in Sierra Leone, which consisted of low social capital as a result of a breakdown in family, communities, trust, and social harmony across society (Solomon \& Ginifer, 2008). To address marginalization, DDR programs must prioritize ex-child soldiers' social capital and community readiness through various initiatives that will facilitate communication, reconciliation, and thereby acceptance of ex-child soldiers in their respective communities.

Although a lot of attention has been given to the issue of child soldiering, the available literature lacks a theoretical foundation that explains the phenomenon 
of child soldiering, the unique needs its victims' experience, or their reintegration experiences based on empirical evidence. This theoretical information will help us understand the relationship between child soldiers' experiences and their current physical, psychological, and social needs as they transition to civilian living. Murphy (2003) argued that due to the complex nature of child soldiers' experiences, and the shift in relationships between children and adult relatives, men and women, elders and youths, ritual power and physical force, coercion and persuasion, reciprocity and cruelty, and wealth and military power, more than one theoretical perspective has to be used to understand child soldiering. In addition, a combination of two or more theories will provide a more thorough explanation of the effect military experiences have on children, families, and the society in general. Such an eclectic theoretical framework will also serve as a theoretical underpinning for possible interventions that can help children successfully reintegrate. The theoretical framework for the present study is a combination of three theories: Erickson's $(1963,1968)$ psychosocial stages of development theory, Bronfrenbrenner's (1986) ecological theory, and Maslow's hierarchy of needs theory (Maslow, 1954, 1971).

Mapp (2008) identified biopsychosocial assessment as a tool that can be used to examine the barriers to reintegration that ex-child soldiers face. On the biological level, child soldiers may endure combat wounds, malnourishment, and limited access to health care, all of which negatively impact their overall physical health. Meanwhile, their experiences of losing loved ones, being forced to murder or witness murders are traumatic experiences that are often sources of psychological discomfort. Lastly, on the social level, ex-child soldiers are challenged with rebuilding relationships with hostile family and community members and topursue education in environments that may be unsuitable for their current age and past violent experiences (Mapp, 2008).

Drawing upon Bronfrenbrenner's ecological theory of development, Kimmel and Roby (2007) suggested a conceptual model for understanding how the interactions between macro and micro factors contribute to child soldiering. Based on the ecological perspective, they argue that three macro factors (politics, policy, and culture and beliefs) interact with each other and have gradual influences on three micro-level factors (community, family, and individual psychosocial factors) that also interact with each other and as a result have negative psychosocial effects on children (Kimmel \& Roby, 2007). The implication for ecological theory on this population is that the unique needs of ex-child fighters are socially mediated; therefore, interventions should be based on a holistic approach, rallying support from children's environments that contribute to their development and well-being.

The ecological theory can assist researchers and practitioners working with this population in identifying available resources and interventions within their micro and mezzo levels (family, peers, or community) as well as resources from macro systems (NGOs and government health agencies). In a study on war experiences of child soldiers in Northern Uganda, researchers caution that in order 
to address potential indirect consequences of child soldiering, support needs to be allocated for the child's network, based on a socio-ecological approach (Vindevogel et al., 2011). The ecological theory provides a framework that explains the influence that systems have on children's physical and mental health and also assists in the recognition of the effect that community and policies have on individuals at the micro-levels (McLeroy, Bibeau, Steckler, \& Glanz, 1988).

The results of this study seem to resonate in several ways with Maslow's hierarchy of needs theory (Maslow, 1954, 1971) and social development theories. Many of the findings of this study are similar to others who studied ex-child soldiers' reintegration experiences (Corbin, 2008; Veale \& Stavrou, 2007; Woodward \& Galvin, 2009) and found that ex-child soldiers lack the resources to meet their basic needs, which makes it extremely difficult and almost impossible to reach full human potential (Walker \& Early, 2010).

After the war, many ex-child soldiers can reunite with their families and return to their communities, expecting to start a new life. However, reintegration was often very challenging, and some ex-child soldiers experienced stigmatization and rejection (Denov, 2010). In terms of social marginalization, participants perceived themselves as disconnected from their communities, both economically and socially. Participants felt that their unemployment and overall poverty situations created a divide between them and their communities. They considered this divide a significant obstacle that prevented community members from recognizing and accepting them as reformed community members. These observations are consistent with studies of ex-child soldiers in Uganda, Sierra Leone, and Nepal by Annan, Blattman, Mazurana, and Carlson (2011), Betancourt et al. (2010), and Kohrt et al. (2010). Their findings suggest that while some child soldiers are accepted back in their communities, many others experience stigmatization. Female ex-child soldiers experienced less community acceptance and support compared to male ex-child soldiers (Annan et al., 2011; Betancourt et al., 2010; Kohrt et al., 2010).

Participants in this study admitted to having some knowledge and skills they acquired from vocational skills training and expressed their willingness to contribute to their various communities if given the opportunity. Similarly, former child soldiers in Boothby and Thomson (2013) indicated that they made a collective effort to be a part of their communities by providing assistance to those in need and engaging in leadership roles. However, amid social marginalization, ex-child soldier participants are prevented from reconnecting with and contributing to their various communities. This finding is similar to a previous study in which Stravou (2006), through interviews with community members, found that social marginalization of ex-child soldiers could be a loss to their communities given the observations of teachers that some ex-combatants were stronger, more confident, and had more leadership skills than youths who were not child soldiers.

In the case of the ex-child soldier participants in this study, their reintegration experience was structurally characterized by poor administration at program 
and government levels, constrained opportunities, and social marginalization. Similarly, Dudwick and Sirinvasan (2013) indicated that reintegration programs had been criticized for lack of funding, inadequate administration, and corruption. When combined with the textural themes of dissatisfaction, powerlessness, and perceptions of no or partial reintegration among ex-child soldiers (Brownell, 2019), these structural themes help explain why the majority of the participants in this study experienced dissatisfaction with the reintegration process, perceived themselves as powerlessness, partially reintegrated and not reintegrated. However, in spite of the poor administration of the DDR program and the subsequent limited reintegration assistance, the findings showed that ex-combatants could become successful when the following conditions are met: when they are internally motivated to change and contribute to societal development; when they successfully complete vocational skills training and receive certificate and tools.

Drawing upon the experience of the only participant who reported full reintegration, adequate program administration, employment, and community acceptance, the findings suggest that participants are likely to obtain full reintegration when they receive adequate reintegration programming, build connections with community members, and perceive acceptance and recognition from community members who recognize their post-war change and behaviors. The participant who reported full reintegration expressed that he believed his community members viewed him as a reformed individual due to his participation in the vocational skills training and his subsequent contributions as an employee of the Liberia Electricity Corporation, a state run electrical energy company.

\section{Implications}

\section{Practice Implications}

Social work practitioners are encouraged to seek knowledge about the phenomena of child soldiering, the background of the Liberian civil war, and the subsequent efforts made to help reintegrate child soldiers. Social workers working with this population should learn about the cultures and the diversity of Liberian child soldiers and the communities with which they are trying to reconnect. Findings from a qualitative study among ex-combatants in Monrovia, Liberia, emphasize the significance of social context. It suggests that reintegration programs incorporate pertinent information regarding conflict histories, socioeconomic conditions, and local institutional capacity that impact ex-combatants (Jennings, 2007). Henceforth, when working with ex-child soldiers on the micro-level, social workers should be mindful of Western approaches, which usually involve encouraging individuals to recollect and talk about past trauma.

Past studies of ex-child soldiers identified key contributors to psychological healing as avoidance of talking about trauma in Uganda (Corbin, 2008) and reliance on families, friends, and themselves in Mozambique (Boothby, 2006). Guided 
by the National Association of Social Workers (NASW) Code of Ethics and the statement of principles provided by the International Federation of Social Workers, social workers are to conduct themselves professionally and with integrity. This means that social workers ought to treat clients with respect and without discrimination regardless of their backgrounds (culture, ethnicity, age, political beliefs, physical or mental disability, etc.), which in the case of Liberian ex-child soldiers include past military experiences. Therefore, social workers working with ex-child soldiers should avoid pathologizing and labeling ex-child soldiers during their reintegration. For instance, in the past literature, several authors used the term "lost generation" to describe ex-child soldiers in Liberia (Kanneh, 1996; Kinkolenge, n.d.; Paintin, 2007). Liberia’s former president, Ellen Johnson Sirleaf, refuted this term and argued that ex-child soldiers be called the "opportunity generation" who need education and vocational training to meet their developmental needs (Parley, 2013).

Another practice implication is the need for community outreach for the purposes of sensitizing and educating ex-child soldiers and their communities about the biopsychosocial effects of child soldiering on the individual and community levels. This community outreach approach will facilitate and encourage ex-child soldiers to work hard during reintegration. At the same time, this community outreach will also promote efforts from community members to recognize and support the efforts ex-child soldiers put during reintegration. Using this community outreach approach, social workers will provide case management to ex-child soldiers and also serve as liaisons between ex-combatants and their communities to reduce the structural theme of social marginalization. In addition, the literature emphasizes the role that cultural practices play in re-establishing relationships between former child soldiers and their communities (Corbin, 2008; Denov, 2010; Honwana, 2006). Thus, we recommend that professionals educate themselves about the cultural practices of Liberian ex-child soldiers and incorporate them into reintegration interventions.

Social workers assisting this population are encouraged to use Erikson's psychosocial development theory to help them understand child soldiers' development during adolescence and how military experience affects their identities. Bronfenbrenner's ecological theory helps to identify available resources and interventions within ex-child soldiers' micro and mezzo levels (family, peers, or community), as well as resources from macrosystems (NGOs and government health agencies), and Maslow's hierarchy of needs theory enables to identify and understand the various needs adult ex-child soldiers experience while adjusting to civilian living. Not only do these findings have implications for social work practice in Liberia, but its implications are also relevant to social work practice and social work education in the West, including the United States. Denov (2010) argued that social work curricula need to prepare social workers with appropriate knowledge, skills, and competencies required to provide services to ex-child soldiers seeking asylum in Western counties. 
Policy Implications

In terms of policy, the findings of this study evidenced a lack of policies to provide funding and action plans for additional reintegration assistance following the conclusion of the national DDR program. Therefore, there is an urgent need for policies geared toward providing reintegration assistance to ex-child soldiers as well as a structural basis for adequate implementation of reintegration programs. Such reintegration programs should adopt evidence-based practices, as suggested in this study, which will help policymakers understand the reintegration experiences of ex-child soldiers in the context of post-war Liberia. While there are several international and national policies that prevent child soldiering in Liberia (Achilihu, 2010; African Union, 2010; Human Rights Watch, 2004), there are no policies in Liberia that empower ex-child soldiers to prevent them from being re-recruited, especially since Liberian ex-child soldiers remain vulnerable to being re-recruited for future armed conflicts as a result of the poverty they experience (Child Soldier International, 2008).

Consequently, funding needs to be allocated for additional reintegration services including but not limited to education (ex-child soldiers and their children), employment (formal or petty trade), housing, community outreach, medical and mental health, which will allow for ex-child soldiers to have a smoother transition from soldier to civilian status. Policymakers also need to focus on a policy that will ensure that ex-child soldiers and their families are safe from discrimination and physical abuse. A policy of this nature will reduce the fear that ex-child soldiers have of their families being be retaliated upon (Qiushi, 2010). Taking into account Liberia's current economic conditions and the funding allocated for reintegration services, policymakers and practitioners are encouraged to develop and implement reintegration intervention goals that are realistic and can assist ex-child fighters acquire marketable employment skills and also create economic opportunities that would empower ex-combatants to meet their basic needs.

\section{Research Implications}

The purpose of this study was to gain a better understanding of the reintegration experiences and meaning of reintegration as perceived by ex-child soldiers located in or near Monrovia, the capital city of Liberia. Furthermore, the study explores participants' hopes and expectations about their reintegration, contributing factors and obstacles to reintegration, perceptions of the extent of their reintegration, and perceptions of future combat participation within the context of Liberia. No other studies of this nature were identified in the literature. Hence, this study should be replicated with a group of ex-child soldiers outside Monrovia for comparative purposes.

In addition to replicating this study with ex-child soldiers in other parts of Liberia, the study could also be replicated with a larger sample. Future studies could 
focus on how ex-child soldiers in the rural parts of Liberia experience and perceive reintegration and how their meaning of reintegration influences their reintegration experience and vice versa. The findings of such a study will contribute to the knowledge base and increase the understanding of ex-child soldiers' reintegration experiences within the cultural and environmental context of other parts of Liberia.

Future researchers replicating this study could include questions to explore other areas of education or vocational skills training that ex-child soldiers are interested in learning based on their strengths, available resources, and the current post-war economy. A future study could focus on an in-depth case analysis of the negative case in this study who reported full reintegration and satisfaction with the reintegration process. Research studies could explore the attributes and characteristics that differentiate the negative case from the rest of the participants, and its findings could be used to develop interventions that could teach or encourage those attributes and characteristics to other ex-child soldiers to facilitate their reintegration process.

Besides future qualitative research on ex-child soldiers' reintegration, mixedmethod studies are also much needed. For instance, studies could utilize guiding questions based on or derived from the ones used in this study but then also incorporate an instrument to measure social indicators of how effectively ex-child soldiers are reintegrating, and this includes constructs related to stress, aggression, biopsychosocial adjustment, and economic sustainability accounting for the current economic conditions of Liberia.

A longitudinal study of ex-child soldiers in Liberia would provide invaluable information and help us understand the long-term experiences of ex-child soldiers as they transition to civilian status. Also, to understandwhat reintegration looks like on a long-term basis, this study will provide evidence of the life outcomes of ex-child soldiers in Liberia. A study of this nature will also measure the effectiveness of helping efforts over a long period and the most efficient use of scarce community resources geared toward assisting ex-child soldiers' reintegration. Building a knowledge base from this effort will inform and serve other ex-combatants in other parts of the world. Lastly, formative program evaluation can assess how the program is being implemented while the reintegration interventions are in process to remove constraints and facilitate enhancements as needed. In addition, summative program evaluation can be used to determine whether or not the program met its goals of improving ex-child soldiers' well-being and, thus, contributed to Liberia's social development.

\section{Final Thoughts}

The macro approach is essential to transform "the how" of social institutions performance/responses and impact "the what" ex-child soldiers' experience during their reintegration to achieve individual and collective well-being. Without adequate administration, implementation, and evaluation, DDR programs 
will remain unsuccessful in improving ex-child soldiers" “ well-being, their communities, and post-conflict societies in general. Thus, to demonstrate that social development has occurred as a result of DDR programs, stakeholders must use program evaluation methods during and after reintegration interventions to demonstrate the effectiveness of the program's administration and outcomes. It is essential to recognize the connection between how DDR programs are administered with the ensuing constrained opportunities and marginalization of ex-child soldiers' experience. Thus, integrating social development strategies involves:

- understanding the ex-child soldier population

- partnering with the communities to share what well-being looks like to them considering their cultural values and traditions

- drawing upon communities and target populations' input to design interventions with an emphasis on empowerment and community development

- evaluating the implementation processes, primarily the administration of the program

- evaluating interventions during and after they are carried out.

- demonstrating whether or not social development has occurred by clearly defining the goals and well-being

\section{References}

Achilihu, S. (2010). Do African children have rights? Boca Raton, FL: Universal Publishers.

Ackerman, R. (2009). Rebuilding Liberia, one brick at a time. World Policy Journal, 26(2), 83. doi:10.1162/wopj.2009.26.2.83

African Union. (2010). List of countries which have signed, ratified/acceded to the African charter on the rights and welfare of the child. Retrieved from https://www.acerwc.africa/ratifications-table/

Agbedahin, K. (2018). Drawing paradise from hell: War retentions and post-conflict reintegration of young veterans in Africa. African Security Review, 27(34), 212-225. doi:10.1080/10246029.2018.1524776

Annan, J., Blattman, C., Mazurana, D., \& Carlson, K. (2011). Civil war, reintegration, and gender in northern Uganda. Journal of Conflict Resolution, 55, 877908. doi:10.1177/0022002711408013

Ansorge, J. T., \& Antwi-Ansorge, N. A. (2011). Monopoly, legitimacy, force: DDR-SSR Liberia. In M. A. Civic \& M. Miklaucic (Ed.), Monopoly of force: The nexus of DDR and SSR (pp. 265-284). Washington, DC: National Defense University.

Awodola, B. (2012). An examination of methods to reintegrate former child soldiers in Liberia. Intervention, 10(1), 30-42. doi:10.1097/WTF.0b013e32834912e3

Betancourt, T. S., Agnew-Blais, J., Gilman, S. E., Williams, D. R., \& Ellis, B. H. (2010). Past horrors, present struggles: The role of stigma in the association between war experiences and psychosocial adjustment among former child 
soldiers in Sierra Leone. Social Science \& Medicine, 70, 17-26. doi:10.1016/j. socscimed.2009.09.038

Boothby, N. (2006). What happens when child soldiers grow up? The Mozambique case study. International Journal of Mental Health, Psychosocial Work E Counseling in Areas of Armed Conflict, 4(3), 244-259. doi:10.1097/ WTF.0b013e32801181ab

Boothby, N., \& Thompson, B. (2013). Child soldiers as adults: The Mozambique case study. Journal of Aggression, Maltreatment E Trauma, 22(7), 735-756. doi:10.1080/10926771.2013.814742

Bowd, R \& Ozerdem, A (2013). How to asses social reintegration of ex-combatants. Journal of Intervention and Statebuilding 7(4), 1-23. doi: 10.1080/1750 2977.2012.727537

Bronfrenbrenner, U. (1986). Ecology of the family as a context for human development: Research perspectives. Developmental Psychology, 22, 723-742. doi:10.1037/0012-1649.22.6.723

Brownell, G. (2019). A phenomenological study of ex-child soldiers' perceived meaning of reintegration in post war Liberia. Journal of Human Behavior in the Social Environment, 30(2), 173-190. doi:10.1080/10911359.2019.1665608

Child Soldier International. (2008). Child soldiers global report 2008 - Liberia. http://www.unhcr.org/refworld/docid/486cb11228.html

Conoir, Y., \& Bonard, P. (2013). Evaluation of UNDP reintegration programs, final evaluation report draft. Unpublished. http://erc.undp.org/evaluationadmin/ downloaddocument.ht

Corbin, J. N. (2008). Returning home: Resettlement of formerly abducted children in northern Uganda. Disasters, 32(2), 316-335. doi:10.1111/j.1467 $-7717.2008 .01042 . x$

Denov, M. (2010). Coping with the trauma of war: Former child soldiers in post-conflict Sierra Leone. International Social Work, 53, 791-806. doi:10.1177/0020872809358400

Druba, V. (2002). The problem of child soldiers. International Review of Education/Internationale Zeitschrift Für Erziehungswissenschaft, 48(3/4), 271-278. doi:10.1023/A:1020309527289

Dudwick, N., \& Sirinvasa, R. (2013). Creating jobs in Africa's fragile states. Are value chains an answer? Washington, DC: World Bank. doi:10.1596/9780-8213-9793-0

Erickson, E. (1963). Childhood and society (2nd ed.) New York, NY: Norton.

Erickson, E. (1968). Identity: youth and crisis. New York, NY: Norton.

Fegley, R. (2008). Comparative perspectives on the rehabilitation of ex-slaves and former child soldiers with special reference to Sudan. African Studies Quarterly, 10(1), 35-69.

Ferreira, R., \& Stuart Muttiti, A. (2016). Creating sustainable community structures for reintegrated Liberian child soldiers: Part I. Commonwealth Youth and Development, 14(2), 12-37. doi:10.25159/1727-7140/1807

Finn, A., Baxter, D., \& Onur, M. (2014). Making vocational training work: A study of vocational training in DDR. Washington, DC: World Bank. 
Gislesen, K. (2006). A childhood lost? The challenges of successful disarmament, demobilization and reintegration of child soldiers: The case of West Africa. Oslo, Norway: Norwegian Institute of Foreign Affairs.

Giustozzi, A. (2012). Introduction. In A. Giustozzi (Ed.), Post-conflict disarmament, demobilization and reintegration: Bringing state building back in (pp. 1-28). Burlington: Ashgate.

González Veiga, T. (2019). A new conceptualization of child reintegration in conflict contexts. E-International Relations. Retrieved April 15, 2020 from https://www.e-ir.info/2019/06/21/a-new-conceptualisation-of-child-reintegration-in-conflict-contexts/

Gregory, J., \& Embrey, D. G. (2009). Companion recovery model to reduce the effects of profound catastrophic trauma for former child soldiers in Ganta, Liberia. Traumatology, 15(1), 40-51. doi:10.1177/ 1534765608326178

Guba, E. G., \& Lincoln, Y. S. (1989). Fourth generation evaluation. Newbury Park, CA: Sage Publications.

Hanson, S. (2007, February 16). Disarmament, demobilization and reintegration in Africa. http://www.cfr.org/publication/12650/

Honwana, A. (2006). Child soldiers in Africa. Philadelphia, PA: University of Pennsylvania Press.

Human Rights Watch. (2004). How to fight, how to kill: Child soldiers in Liberia. Human Rights Watch, 16(2). https://www.hrw.org/report/2004/02/02/ how-fight-how-kill/child-soldiers-liberia

Human Rights Watch. (2005). Youth, poverty and blood: The lethal legacy of West Africa's regional warriors [summary]. http://hrw.org/reports/2005/ westafrica0405/1.htm\#_Toc98324919

International Peace Academy. (2002). Workshop report: A framework for lasting disarmament, demobilization, and reintegration of former combatants in crisis situations. https://www.ipinst.org/wp content/uploads/publications/ framework_for_ddr.pdf

Jaye, T. (2009). Transitional justice and DDR: The case of Liberia. International Centre for Transitional Justice. https://ictj.org/sites/default/files/ICTJ-DDR-Liberia-CaseStudy-2009-English.pdf

Jennings, K. M. (2007). The struggle to satisfy: DDR through the eyes of ex-combatants in Liberia. International Peacekeeping, 14(2), 204-218. doi:10.1080/ 13533310601150800

Kanneh, J. (1996). Liberia the lost generation. Scholastic Update, 128(10), 5. doi: $10.1080 / 13533310601150800$

Kaplan, O., \& Nussio, E. (2018). Community counts: The social reintegration of ex-combatants in Colombia. Conflict Management and Peace Science, 35(2), 132-153. doi:10.1177/0738894215614506

Kilroy, W. (2014). Does a more participatory approach to reintegrating ex-combatants lead to better outcomes? Evidence from Sierra Leone and Liberia. Conflict, Security \& Development, 14(3), 275-308. doi:10.1080/14678802. 2014.923151 
Kimmel, C., \& Roby, J. (2007). Institutionalized child abuse: The use of child soldiers. International Social Work, 50(6), 740-754. doi:10.1177/0020872807081901

Kinkolenge, F. (n.d.). Peace and wholeness for the "lost generation" of Liberia's children. http://www.umcmission.org/Find-Resources/New-World-OutlookMagazine/New-World-Outlook-Archives/2012/NWO-November/December2012/Peace-and-Wholenessfor-the-Lost-Generation-of-Liberias Children\# sthash.j5jwEiGg.dpufhttp://www.umcmission.org/Find-Resources/ New-World-Outlook-Magazine/New-World-Outlook Archives/2012/NWONovember/December2012/Peace-and-Wholenessfor-the-Lost-Generation-ofLiberias-Children

Kohrt, B. A., Tol, W. A., Pettigrew, J., \& Karki, R. (2010). Children and revolution: The mental health and psychosocial well-being of child soldiers in Nepal's Maoist army. In M. Singer \& G. D. Hodge (Eds.), The war machine and global health (pp. 89-116). Lanham, MD: Altamira Press: Rowan \& Littlefield.

Lekskes, J., van Hooren, S., \& de Beus, J. (2007). Appraisal of psychosocial interventions in Liberia. Intervention: International Journal of Mental Health, Psychosocial Work E Counselling in Areas of Armed Conflict, 5(1), 18. doi:10.1097/ WTF.0b013e3280be5b47.

Levey, E. J., Borba, C. P. C., Harris, B. L., Carney, J. R., Domínguez, S., Wang, E. K. S., \& Henderson, D. C. (2013). Assessment of the needs of vulnerable youth populations in post-conflict Liberia. African Journal of Psychiatry, 16(5), 349-355. doi:10.4314/ajpsy.v16i5.47

Lord, J. E., \& Stein, M. A. (2015). Peacebuilding and reintegrating ex-combatants with disabilities. The International Journal of Human Rights, 19(3), 277-292. doi:10.1080/13642987.2015.1031515

Mapp, S. (2008). Human rights and social justice in a global perspective: An introduction to international social work. New York, NY: Oxford University Press.

Maslow, A. H. (1954). Motivation and personality. New York, NY: Harper \& Row.

Maslow, A. H. (1971). The farther reaches of human nature. New York, NY: Viking.

McLeroy, K., Bibeau, D., Steckler, A., \& Glanz, K. (1988). An ecological perspective on health promotion programs. Health Education Quarterly, 15(4), 351-377. doi:10.1177/109019818801500401

McMullin, J. R. (2013a). Ex-combatants and the post-conflict state challenges of reintegration. Basingstoke: Palgrave Macmillan. doi:10.1057/9781137312938

McMullin, J. R. (2013b). Integration or separation? The stigmatization of ex-combatants after war. Review of International Studies, 39(2), 385-414. doi:10.1017/S0260210512000228

Moustakas, C. (1994). Phenomenological research methods. Thousand Oaks, CA: Sage. Munive, J., \& Stepputat, F. (2015). Rethinking disarmament, demobilization and reintegration programs. Stability: International Journal of Security \& Development, 4(1), 1-13. doi:10.5334/sta.go

Murphy, W. P. (2003). Military patrimonialism and child soldier clientalism in the Liberian and Sierra Leonean civil wars. African Studies Review, 46(2), 61. doi:10.2307/1514826 
Padgett, D. (2008). Qualitative methods in social work research (2nd ed.). Los Angeles, CA: Sage Publications.

Paes, W. (2005). The challenges of disarmament, demobilization and reintegration in Liberia. International Peacekeeping, 12(2), 253-261. doi:10.1080/ 13533310500066537.

Paintin, K. (2007). The lost generation. Public Policy Research, 14, 229-233. doi:10.1111/j.1744-540X.2008.00494.x

Palmer, K. (2006, August 31). A costly farewell to arms? African nations try to curb combat by paying fighters to give up weapons. Toronto Star (Canada), p. C1.

Parley, W. (2013). Liberia: Ellen resists "lost generation" debate. http://allafrica. com/stories/201305230822.html

Patton, M. Q. (2002). Qualitative research E evaluation methods (3rd ed.). Thousand Oaks, CA: Sage Publications.

Peters, L. (2005). Child soldiers - Recruitment, demobilization, rehabilitation, reintegration. Developing Strategies to Deal with Trauma in Children, 1(1), 40-52.

Pillai, V. K. (2017). Social development - A search for conceptual linkages. Social Development Issues: Alternative Approaches to Global Human Needs, 39(1), 1-10.

Podder, S. (2010). Mapping child soldiers' reintegration outcomes in Liberia: A participatory approach. In A. Özerdem \& R. Bowd (Eds.), Participatory research methodologies: Development and post-disaster/conflict reconstruction (pp. 165-180). http://ebookcentral.proquest.com

Podder, S. (2012). From recruitment to reintegration: Communities and ex-combatants in post conflict Liberia. International Peacekeeping, 19(2), 186-202. doi:10.1080/13533312.2012.665696

Pugel, J. (2007). What the fighters say: A survey of ex-combatants in Liberia. United Nation Development Program. http://www.operationspaix.net/DATA/DOCUMENT/904 V What_the_Fighters_Say_A_Survey_of_Ex-combatants_ in_Liberia.pdf

Qerimi, Q. (2018). The quest for operational priorities: Areas in need of strategic development intervention. Law and Development Review, 11(1), 1-29. doi:10.1515/ldr-2017-0007

Qiushi, Y. (2010). My child shall be protected: A former child soldier's commitment to his son. UN Chronicle, 47(4), 36-41. doi:10.18356/cf906df6-en

Sam-Peal, E. (2008). Pastor Emile's children. International Journal of Children's Spirituality, 13(3), 235-239. doi:10.1080/13644360802236672

Schulhofer-Wohl, J., \& Sambanis, N. (2010). Disarmament, demobilization, and reintegration programs: An assessment. Folke Bernadotte Academy Publications, Sandoverken, Sweden.

Shakya, A. (2010). Experiences of children in armed conflict in Nepal. Children and Youth Services Review, 33, 557-563. doi:10.1016/j.childyouth.2010.08.018

Söderström, J. (2009, September 3-6). In the midst of cynicism \& faith: Avenues of participation among Ex-Combatants in Liberia [Paper presentation]. APSA Annual Meeting, Toronto, Canada.

Solomon, C., \& Ginifer, J. (2008). Disarmament, demobilization and reintegration in Sierra Leone. Center for International Cooperation and Security. https://au.int/ 
sites/default/files/documents/39119-doc-85._disarmament_demobilisation_ and_reintegration_in_sierra_leone.pdf

Stravou, V. (2006). Breaking the silence: Girls forcibly involved in the armed struggles in Angola. Childs Rights International Network. https://archive.crin.org/en/ library/publications/breaking-silence-girls-forcibly-involved-armed-struggle-angola-0.html

Subedi, D. B. (2014). Conflict, combatants, and cash: Economic reintegration and livelihoods of ex-combatants in Nepal. World Development, 59, 238-250. doi:10.1016/j.worlddev.2014.01.025

Tonpo, J. A. (2006). Liberia turning swords into ploughshares. New African, 448, $50-51$.

United Nations. (1986). Declaration on the right to development. https://www. un.org/en/events/righttodevelopment/declaration.shtml

United Nations Children's Fund (UNICEF). (2009). Liberia enshrines the convention on the rights of the child in military code. http://www.unicef.org/protection/ liberia_51970.html

United Nations, Department of Economic and Social Affairs, Sustainable Development. (n.d.). Sustainable development goals. https://sdgs.un.org/goals

United Nations, Development Program. (n.d.). Human development reports. http:// hdr.undp.org/en/humandev

United Nations, Disarmament, Demobilization and Reintegration Resource Centre. (2020). Integrated Disarmament, Demobilization, and Reintegration Standards (IDDRS). https://www.unddr.org/the-iddrs/

United Nations, Mission in Liberia. (2020). About. https://unmil.unmissions.org/ about

Veale, A., \& Stavrou, A. (2007). Former lord's resistance army child soldier abductees: Explorations of identity in reintegration and reconciliation. Peace and Conflict: Journal of Peace Psychology, 13(3), 273-292. doi:10.1080/10781910701471306

Vindevogel, S., Coppens, K., Derluyn, I., De Schryver, M., Loots, G., \& Broekaert, E. (2011). Forced conscription of children during armed conflict: Experiences of former child soldiers in northern Uganda. Child Abuse \& Neglect, 35(7), 551-562. doi:10.1016/j.chiabu.2011.03.01

Walker, A., \& Early, J. (2010). "We have to do something for ourselves": Using photo voice and participatory action research to assess the barriers to caregiving for abandoned and orphaned children in Sierra Leone. International Electronic Journal of Health Education, 13, 33-48.

Wessells, M. (2005). Child soldiers, peace education, and post-conflict reconstruction for peace. Theory into Practice, 44(4), 363-369. doi:10.1207/ s15430421tip4404_10

Woodward, L., \& Galvin, P. (2009). Halfway to nowhere: Liberian former child soldiers in a Ghanaian refugee camp. Annals of the Association of American Geographers, 99(5), 1003-1011. doi:10.1080/00045600903245698

Zena, P.N. (2013). Lessons and limits of DDR in Africa. https://africacenter.org/ publication/the-lessons-and-limits-of-ddr-in-africa/ 